\title{
Early Iron Age gold buttons from South-Western Iberian Peninsula. Identification of a gold metallurgical workshop
}

\author{
Estudio de botones de oro de la primera Edad del Hierro del Sudoeste de la Península \\ Ibérica. Identificación de un taller metalúrgico de oro
}

\author{
António M. Monge Soares (*) \\ Pedro Valério $(*)$ \\ Rui J. C. Silva (**) \\ Luis Cerqueira Alves $(* * *)$ \\ Maria de Fátima Araújo (*)
}

\begin{abstract}
Early Iron Age gold buttons from Castro dos Ratinhos, Fortios and Outeiro da Cabeça were analysed by conventional EDXRF, Micro-PIXE, SEM-EDS and Optical Microscopy. EDXRF results point out to a rather homogeneous alloy composition throughout all the analysed buttons. PIXE microanalyses show that all the button components (disk, tab and peripheral grooved decorated rod) have the same alloy composition. PIXE and SEM-EDS microanalyses, supplemented with optical microscopy characterization, show the absence of chemical composition differences between distinct components and joining zones, suggesting that no solder had been applied, i.e. that a partial melting/solid state diffusion process had been used for the welding of button components. Finally, the noticeable similar compositions together with the use of the same welding process and the very similar artefact typologies suggest that those small gold treasures could be interpreted as the result of the work of a single metallurgical workshop, probably located somewhere in the South-Western Iberian Peninsula.
\end{abstract}

\section{RESUMEN}

Botones de oro pertenecientes a la primera Edad del Hierro, procedentes de Castro dos Ratinhos, Fortios e Outeiro da Cabeça (Portugal), fueron analizados por

(*) Environmental and Analytical Chemistry, Instituto Tecnológico e Nuclear, Estrada Nacional 10, 2686-953 Sacavém, Portugal. Correos electrónicos: amsoares@itn.pt; pvalerio@itn.pt; faraujo@itn.pt

(**) CENIMAT/I3N, Campus da FCT/UNL, 2829-516 Monte da Caparica, Portugal. E-mail: rjcs@fct.unl.pt
EDXRF y Micro-PIXE. Los resultados de los análisis por EDXRF mostraron una composición similar en todos los botones, independientemente de su procedencia. Por otra parte, los microanálisis por PIXE permitieron verificar que los componentes soldados de cada botón (disco, presilla y cordón exterior) tienen la misma composición química. Además de eso, las áreas de soldadura fueron estudiadas mediante Micro-PIXE, SEM-EDS y posterior análisis metalográfico por microscopia óptica de reflexión. Estos análisis permitieron comprobar la ausencia de soldaduras en las zonas de unión de estos componentes, lo que nos permite concluir que debe haber tenido lugar un proceso de fusión parcial y de difusión en estado sólido para unir los componentes de estos botones. La gran semejanza en la composición química, junto a la presencia del mismo tipo de soldadura y tipologías similares, nos sugiere que todas estas piezas fueron resultado del trabajo de un mismo artesano-joyero, cuyo taller se encontraría localizado en el sudoeste de la Península Ibérica.

Key words: Gold alloy; Early Iron Age; South-Western Iberian Peninsula; Welding; Metallurgical workshop; EDXRF; Micro-PIXE; SEM-EDS; Optical Microscopy.

Palabras clave: Oro; Primera Edad del Hierro; Sudoeste de la Península Ibérica; Soldadura; Taller de metalurgia; EDXRF; Micro-PIXE; SEM-EDS; Microscopía Óptica de Reflexión.

(***) Ion Beam Laboratory, Instituto Tecnológico e Nuclear, Estrada Nacional 10, 2686-953 Sacavém, Portugal. Correo electrónico: 1calves@itn.pt

Recibido: 19-II-2010; aceptado: 26-IV-2010. 


\section{INTRODUCTION}

A set of seven gold buttons were recovered during recent archaeological excavations at Castro dos Ratinhos (Fig. 1). This archaeological site is an important proto-historic fortified settlement at the Guadiana Valley, located close to the Alqueva Dam. Since 2004, archaeological excavations revealed the presence and monumentality of a defensive system with several wall lines, slopes and a deep ditch (Silva and Berrocal-Rangel 2005). The archaeological record has also shown two main occupation phases: an older one dated from the Late Bronze Age, which is followed by an Early Iron Age occupation that ends still during the 8th century BC. The ruins of a large palace-like building that stands up at the highest place of the settlement, a true acropolis, was uncovered during the 2006 field campaign. The seven small gold buttons were recovered in that building during archaeological digging. The archaeological record suggests that this gold treasure was hidden in some moment during the 8 th century $\mathrm{BC}$, when the large building in the acrop-

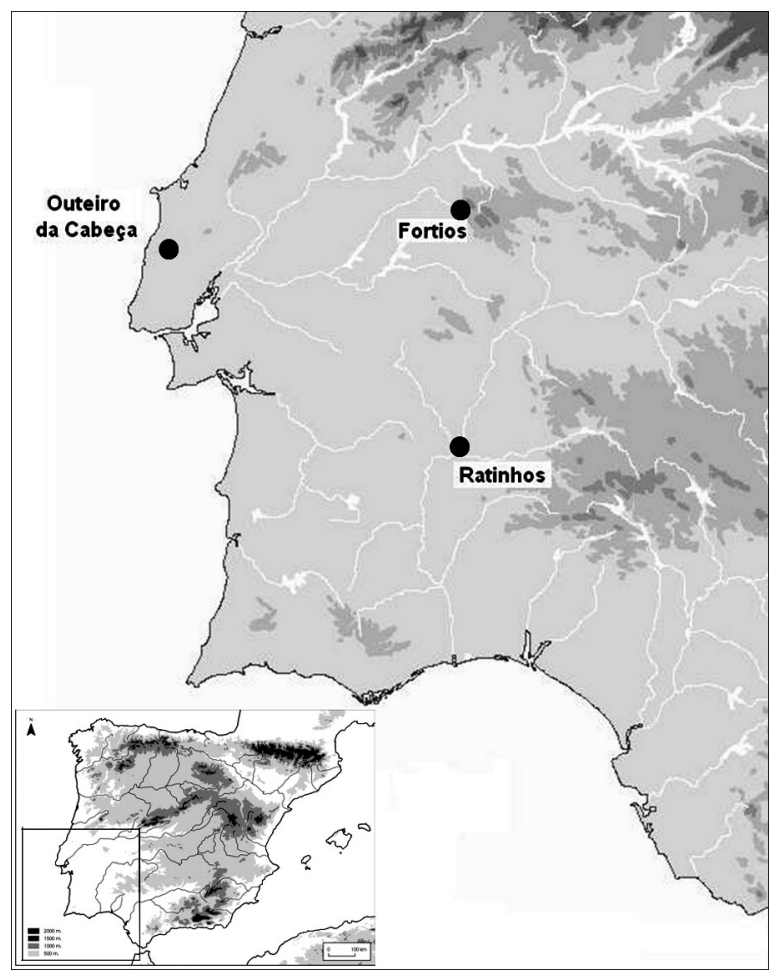

Fig. 1. Location of the 3 treasure finds in the South-Western Iberian Peninsula. olis was abandoned, probably due to violent events. Close to the gold buttons a woven fabric imprint in a bit of clay was discovered suggesting that the jewels were sewn to the tissue using the small tab in the reverse of each button (Berrocal-Rangel and Silva 2007).

Two other sets of gold buttons very similar from the typological point of view to those from Castro dos Ratinhos were found some years ago at Fortios and Outeiro da Cabeça (Fig. 1) without any known or recorded archaeological context.

In the early seventies of last century, some tens of gold buttons were found inside a ceramic pot during the ploughing of a land not far from Fortios (Portalegre). Some of them were acquired by the National Archaeological Museum (MNA), at Lisbon, while others enter private collections. In a preliminary study of eleven of these gold buttons, where their typology is described, this small gold treasure was wrongly ascribed to the Chalcolithic Period (Ferreira 1974).

At Outeiro da Cabeça (Torres Vedras), during the thirties of last century, in an arable land at a place called Casal das Passadeiras, other tens of gold buttons together with some gold jewels belonging to a necklace plus ear-rings, bracelets and also two possible ingots were discovered. Pieces of charcoal seen in the spot where the treasure was recovered led to the hypothesis that a goldsmith workshop would be located at that place. Nevertheless, no other kinds of remains were found and the charcoal could be the result of a more recent forest fire. Due to the jewels typology the treasure was ascribed to the Early Iron Age (Heleno 1935). Some of the buttons and also some of the other jewels, with the exception of the bracelets which fate is unknown, were acquired by the MNA and the Torres Vedras Museum.

Several analytical techniques, namely Energy Dispersive X-Ray Fluorescence spectrometry (EDXRF), Micro-Particle Induced X-Ray Emission spectrometry (Micro-PIXE), Scanning Electron Microscopy (SEM-EDS), and Optical Microscopy $(\mathrm{OM})$, were used to determine the alloy composition and to investigate the welding process applied to join the button components.

\section{BUTTONS TYPOLOGY}

The gold buttons have remarkable similar typologies (Fig. 2). Each one is formed by a thin 

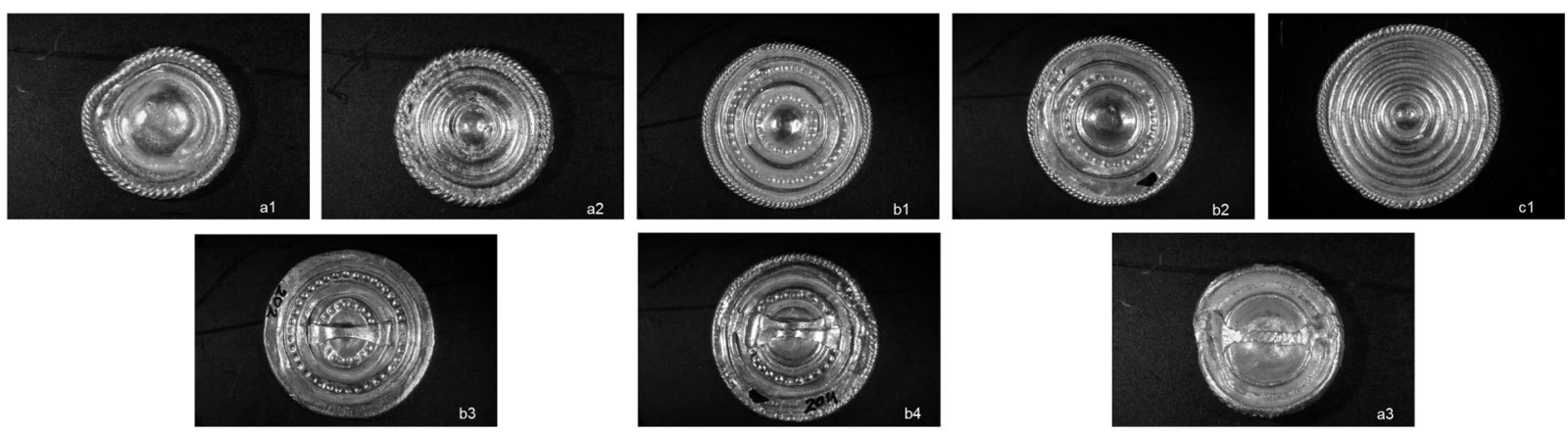

Fig. 2. Buttons typology: a - Castro dos Ratinhos; b - Outeiro da Cabeça; c - Fortios.

flat circular body - a disk - with central spherical decoration in relief enclosed by several engraved circles. On the obverse face of the button a grooved decorated rod is welded to the disk periphery. The reverse of each button exhibits one or two tabs that are made up by a small fragment of the decorated rod that had been flattened, sometimes so extensively that removed all traces of decoration. A simple visual examination of the buttons allows us to identify that the peripheral decorated rod and the tab or tabs were welded on the main disk.

The dimension of the central decoration and number of circles can be used to subdivide the collection of buttons from Castro dos Ratinhos $(\varnothing \approx 10 \mathrm{~mm} ; \mathrm{wt} \approx 0.4 \mathrm{~g})$ in two groups - buttons with small central decoration and additional engraved circles and buttons with larger central decoration and fewer circles. The same occurs for Outeiro da Cabeça. These jewels have a higher diameter $(\varnothing \approx 16 \mathrm{~mm} ; \mathrm{wt} \approx 0.8 \mathrm{~g})$ than those from Castro dos Ratinhos and one or two of the circles are formed by small points punched in relief instead of continuous smooth circles. The buttons from Fortios exhibit the largest diameter $(\varnothing \approx 20$ $\mathrm{mm} ; \mathrm{wt} \approx 1.4 \mathrm{~g}$ ) and a decoration that only differs from the ones of Castro dos Ratinhos in the higher number of concentric circles.

\section{METHODOLOGY AND RESULTS}

The study of diverse archaeological finds, such as it is the case of these gold buttons, must rely mainly on non invasive techniques due to their exceptional significance or unique characteristics and rarity. EDXRF and Micro-PIXE are non invasive, multielemental and relatively fast techniques, which have been frequently used in the chemical characterization of archaeological metallic materials, namely gold artefacts and solder alloys (Demortier 1991; Demortier et al. 1999; Alves et al. 2002; Bugoi et al. 2003; Soares et al. 2004). Nevertheless, sometimes it is not possible to solve research problems only with a non invasive approach. It is the case concerning the identification of the welding process used in the joining of the buttons components. PIXE and SEM-EDS microanalyses, supplemented by metallographic analyses carried out by OM, on a very small bit cut from a gold button already fragmented allowed identifying safely the welding process used.

\section{Alloy Composition}

\section{EDXRF}

EDXRF analyses were made in a Kevex 771 spectrometer equipped with a rhodium X-ray tube as the primary excitation source. Each artefact was irradiated during $300 \mathrm{~s}$ on the obverse and reverse faces, by the characteristic X-rays of a gadolinium secondary target $(57 \mathrm{kV}$, tube voltage, and $2.0 \mathrm{~mA}$, current intensity) and a silver secondary target $(35 \mathrm{kV}$ and $0.5 \mathrm{~mA}$ ). The characteristic X-rays emitted by the elements present in the gold alloy were collimated at $90^{\circ}$ and measured in a $\mathrm{Si}(\mathrm{Li})$ detector with a resolution of 175 $\mathrm{eV}$ at $5.9 \mathrm{keV}(\mathrm{Mn}-\mathrm{K} \alpha)$.

The quantification procedure uses experimental calibration factors and relies on fundamental parameters to account for matrix effects (Tertian and Claisse 1982). The experimental factors were calculated with the analysis of standard materials 
- gold alloyed with silver $(9.85 \%)$ and gold alloyed with copper $(9.98 \%)$. The accuracy of the EDXRF elemental quantification, calculated through the analysis of gold-silver and gold-copper alloys, was found to be better than $1 \%$ for gold, $5 \%$ for silver and $10 \%$ for copper (Araújo et al. 1993).

The obverse and reverse faces of each button were analyzed in order to identify eventual compositional deviations due to different artefact geometries (e.g. convex and concave surfaces), different components (main body, decorated rod and tab) and welded areas (connection of main body/rod and main body/tab).

The elemental composition determined by EDXRF of the gold buttons from Castro dos Ratinhos were already published (Valério et al., 2008). Obverse and reverse faces of each button present almost identical gold, silver and copper contents, which also occurs with the buttons from Outeiro da Cabeça and Fortios. The elemental composition of gold alloys is given as the average of the obverse and reverse button results (Tab. 1).

As at Outeiro da Cabeça the treasure find was composed not only by gold buttons but also by other jewels, namely a necklace, two ear-rings and two possible ingots, these ingots (Fig. 3) and ear-rings plus some of the necklace components (Fig. 4) were also analyzed by EDXRF in two different areas. The average results are presented in table 2.

\section{Micro-PIXE}

Due to the diameter of the incident beam, each EDXRF analysis corresponds to the entire face of the button, compositional variations were further investigated using micro analyses. Micro-PIXE analyses were performed with an Oxford Microbeams type set-up, using a $2 \mathrm{MeV}$ proton beam
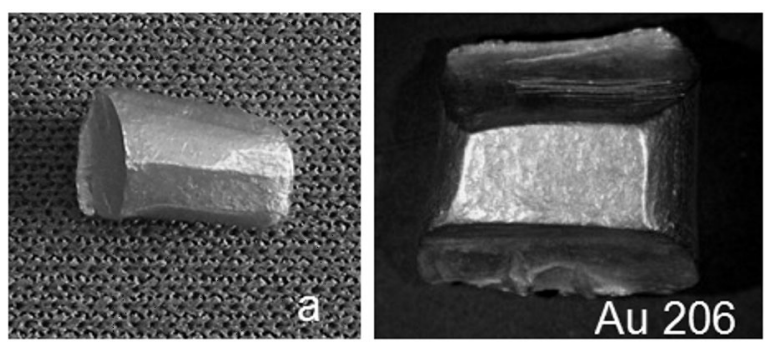

Fig. 3. Ingots from Outeiro da Cabeça.

\begin{tabular}{|c|c|c|c|}
\hline Button Ref. & Au $(\%) *$ & $\operatorname{Ag}(\%) *$ & $\mathrm{Cu}(\%) *$ \\
\hline \multicolumn{4}{|c|}{ Castro dos Ratinhos } \\
\hline CRAT06.1 & 83.2 & 15.0 & 1.7 \\
\hline CRAT06.2 & 84.0 & 14.6 & 1.4 \\
\hline CRAT06.3 & 83.2 & 15.1 & 1.7 \\
\hline CRAT06.4 & 83.3 & 15.0 & 1.7 \\
\hline CRAT06.5 & 83.4 & 14.8 & 1.8 \\
\hline CRAT06.6 & 85.3 & 13.0 & 1.7 \\
\hline CRAT06.7 & 82.8 & 15.5 & 1.8 \\
\hline \multicolumn{4}{|c|}{ Outeiro da Cabeça } \\
\hline Au197 & 86.8 & 11.7 & 1.5 \\
\hline Au198 & 84.6 & 13.7 & 1.8 \\
\hline Au199 & 87.7 & 11.1 & 1.2 \\
\hline $\mathrm{Au} 200$ & 87.2 & 12.1 & 0.7 \\
\hline Au201 & 87.8 & 11.3 & 0.8 \\
\hline $\mathrm{Au} 202$ & 85.8 & 12.9 & 1.4 \\
\hline Au203 & 87.3 & 10.9 & 1.9 \\
\hline Au204 & 84.6 & 13.7 & 1.7 \\
\hline Au205 & 87.2 & 12.0 & 0.8 \\
\hline Au593 & 86.2 & 12.3 & 1.4 \\
\hline 1707 & 85.0 & 12.9 & 2.1 \\
\hline 1711 & 86.7 & 12.4 & 0.9 \\
\hline 1712 & 84.9 & 13.2 & 1.8 \\
\hline 1713 & 88.0 & 11.0 & 1.0 \\
\hline 1714 & 85.6 & 11.5 & 2.8 \\
\hline 1715 & 86.1 & 12.8 & 1.0 \\
\hline 1716 & 85.9 & 13.0 & 1.0 \\
\hline 1717 & 86.7 & 12.6 & 0.7 \\
\hline 1718 & 84.8 & 13.2 & 1.9 \\
\hline 1719 & 87.4 & 11.2 & 1.2 \\
\hline $\mathrm{A}$ & 87.3 & 11.7 & 0.9 \\
\hline B & 86.5 & 12.7 & 0.8 \\
\hline $\mathrm{C}$ & 86.2 & 12.0 & 1.8 \\
\hline \multicolumn{4}{|c|}{ Fortios } \\
\hline Au235 & 85.0 & 13.7 & 1.2 \\
\hline $\mathrm{Au} 237$ & 84.9 & 13.8 & 1.3 \\
\hline $\mathrm{Au} 248$ & 85.5 & 13.0 & 1.4 \\
\hline $\mathrm{Au} 252$ & 85.5 & 13.1 & 1.3 \\
\hline $\mathrm{Au} 253$ & 85.6 & 13.0 & 1.4 \\
\hline
\end{tabular}

Table 1. EDXRF results of gold buttons.

* Mean value taking into account the obverse and the reverse button composition.

generated by a $2.5 \mathrm{MV}$ Van de Graaf accelerator. The X-rays emitted by sample elements were collected by an $80 \mathrm{~mm}^{2} \mathrm{Si}(\mathrm{Li})$ detector placed at a backward angle of $45^{\circ}$ and with $150 \mathrm{eV}$ of resolution. Beam currents of $100 \mathrm{pA}$ were used for all spectra and the beam spatial resolution was kept

T. P., 67, N. ${ }^{\circ} 2$, julio-diciembre 2010, pp. 501-510, ISSN: 0082-5638

doi: $10.3989 /$ tp.2010.10053 


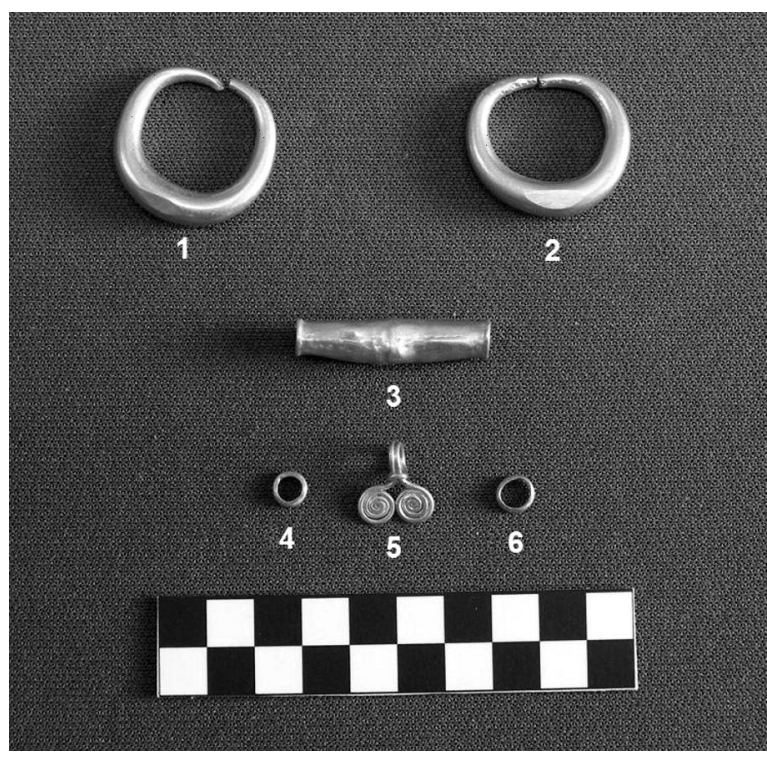

Fig. 4. Ear-rings (1 and 2) and necklace components (3 to 6) from Outeiro da Cabeça.

\begin{tabular}{|lc|c|c|c|}
\hline \multicolumn{1}{|c|}{ Jewel * } & & $\begin{array}{c}\mathbf{A u} \\
\mathbf{( \% )}\end{array}$ & $\begin{array}{c}\mathbf{A g} \\
\mathbf{( \% )}\end{array}$ & $\begin{array}{c}\mathbf{C u} \\
\mathbf{( \% )}\end{array}$ \\
\hline Ear-ring («Xorca») & 1 & 83,0 & 14,0 & 2,86 \\
Ear-ring («Xorca») & 2 & 87,6 & 11,1 & 1,20 \\
Hollow cylinder & 3 & 85,0 & 12,2 & 2,80 \\
Ring & 4 & 78,9 & 18,8 & 2,36 \\
Ring & 6 & 78,7 & 19,4 & 1,90 \\
Coiled wire & 5 & 80,7 & 18,2 & 1,11 \\
Ingot & $\mathrm{a}$ & 83,8 & 15,1 & 1,09 \\
Ingot & Au206 & 89,4 & 10,2 & 0,37 \\
\hline
\end{tabular}

Table 2. EDXRF results of ingots and necklace components from Outeiro da Cabeça.

* See Figs. 3 and 4.

at 2-3 $\mu \mathrm{m}$. The data acquisition and beam scan were controlled by the OMDAQ system and spectra analysis done with the GUPIX computer code (Alves et al. 2000).

Obverse and reverse faces of the buttons were scanned over several selected areas $(2640 \times 2640$ $\mu \mathrm{m}^{2}$ ) to obtain the elemental distributions maps. Some points in these areas were chosen for quantitative analysis. Particular attention was paid on the reverse face of some buttons since from there it would be possible to investigate possible compositional differences between disk, tab, peripheral rod and welded areas.

Results obtained from the gold buttons from Castro dos Ratinhos are presented in table 3. It

\begin{tabular}{|c|c|c|c|c|}
\hline Button & $\begin{array}{c}\text { Com- } \\
\text { ponent }\end{array}$ & Au (\%) & Ag (\%) & Cu (\%) \\
\hline \multirow{3}{*}{ CRAT06.1 } & disk & 89.0 & 8.1 & 2.7 \\
& tab & 86.6 & 11.4 & 1.9 \\
& disk & 89.3 & 9.4 & 1.3 \\
CRAT06.2 & rod & 89.4 & 9.2 & 1.3 \\
& tab & 90.0 & 8.5 & 1.4 \\
& tab & 88.2 & 10.0 & 1.7 \\
& disk & 88.3 & 9.8 & 1.6 \\
CRAT06.3 & tab & 89.8 & 8.8 & 1.3 \\
& disk & 87.0 & 11.0 & 1.8 \\
& tab & 86.5 & 9.7 & 3.5 \\
& disk & 89.4 & 9.1 & 1.4 \\
CRAT06.5 & tab & 88.4 & 9.1 & 2.3 \\
& disk & 88.0 & 9.4 & 2.0 \\
& tab & 89.0 & 8.2 & 2.6 \\
& disk & 86.1 & 12.1 & 1.5 \\
& tab & 87.0 & 11.2 & 1.6 \\
\hline
\end{tabular}

Table 3. Micro-PIXE results of gold buttons from Castro dos Ratinhos.

must be noted that as mentioned before tabs were made from flattened fragments of the rods that were latter welded to disk periphery.

\section{Welding Process}

Micro-PIXE analyses of buttons welded areas did not identify any significant compositional differences that could indicate the presence of a solder alloy (Fig. 5).

Nevertheless, if the solder material is restricted to a small area between two attached components it could be possible that the solder material would not be reachable by this non invasive approach. As one of the buttons is reduced to a fragment (Fig. 6a,b), a small representative fragment from a welded area (disk/rod) was sampled. The fragment was mounted in epoxy resin, polished with SiC papers (P1000, P2500 and $\mathrm{P} 4000)$ and finished with $1 \mu \mathrm{m}$ and $1 / 4 \mu \mathrm{m}$ diamond pastes. The mounted sample was etched with aqua regia and observed in a Leica DMI $5000 \mathrm{M}$ optical microscope under bright field. The optical microscopy images of this cross section clearly identify both button components (rod 


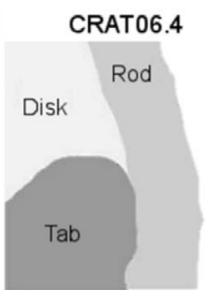

CRAT06.6

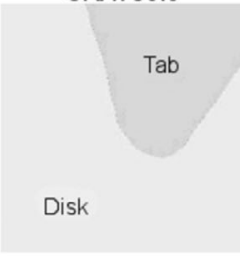

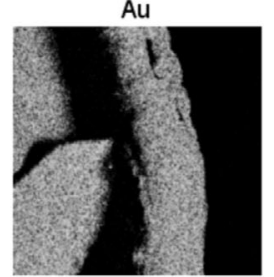

$\mathrm{Au}$

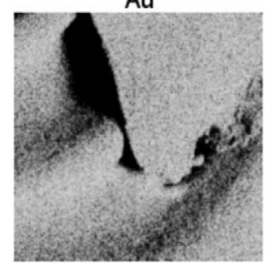

$\mathrm{Ag}$

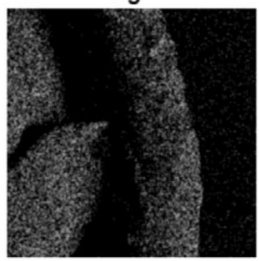

$\mathrm{Ag}$

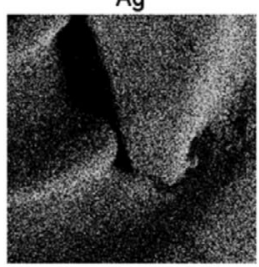

$\mathrm{Cu}$

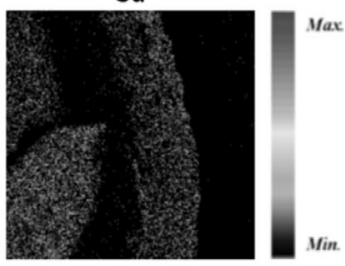

$\mathrm{Cu}$

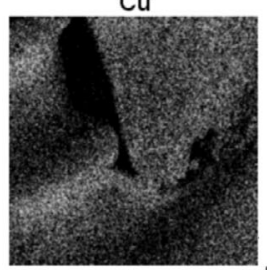

Fig. 5. Maps of gold, silver and copper distribution obtained by micro-PIXE analyses of welded areas of gold buttons from Castro dos Ratinhos.

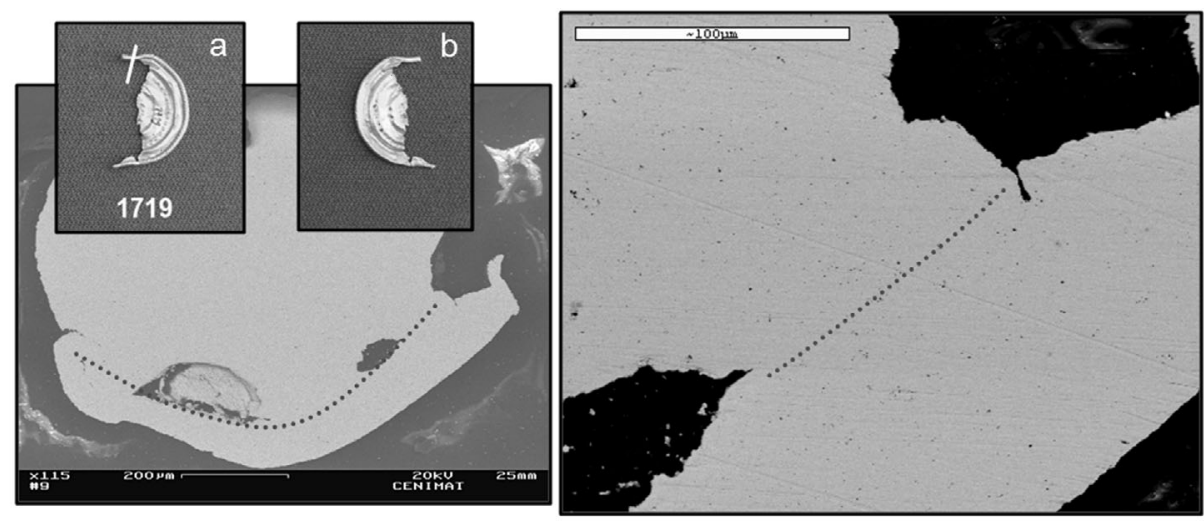

Fig. 6. SEM images of cross section of gold button 1719 from Outeiro da Cabeça (a and b obverse and reverse faces with the location of the cross section; dotted line divides the rod and the disk button components).

and disk) due to their distinct microstructural characteristics, i.e. different grain size (Fig. 7). No solder material is identified between the two components. Furthermore, the presence of annealing twins indicates the use of mechanical and thermal operations in the production of both button components.

SEM-EDS analyses were performed in a Zeiss DSM 962 scanning electron microscope with a secondary electrons detector, a backscattered electrons detector and an Oxford Instruments INCAx-sight EDS spectrometer. Two areas of the mounted cross section containing the two button components were analysed (Figs. 6 and 8a,b), establishing that the gold, silver and copper con- tents remain almost constant throughout the analysed profiles (observed deviations along line scans are due to topographic differences, e.g. scratches or pores). Furthermore, Micro-PIXE analyses also reveal a regular elemental composition in the rod and disk joining area (Fig. 9), presenting these components almost identical compositions, e.g. point 1 (disk) analysis compared to points 3-5 (rod) analyses.

\section{DISCUSSION}

EDXRF results (Tab. 1) show that all buttons are composed by gold alloys with similar silver 

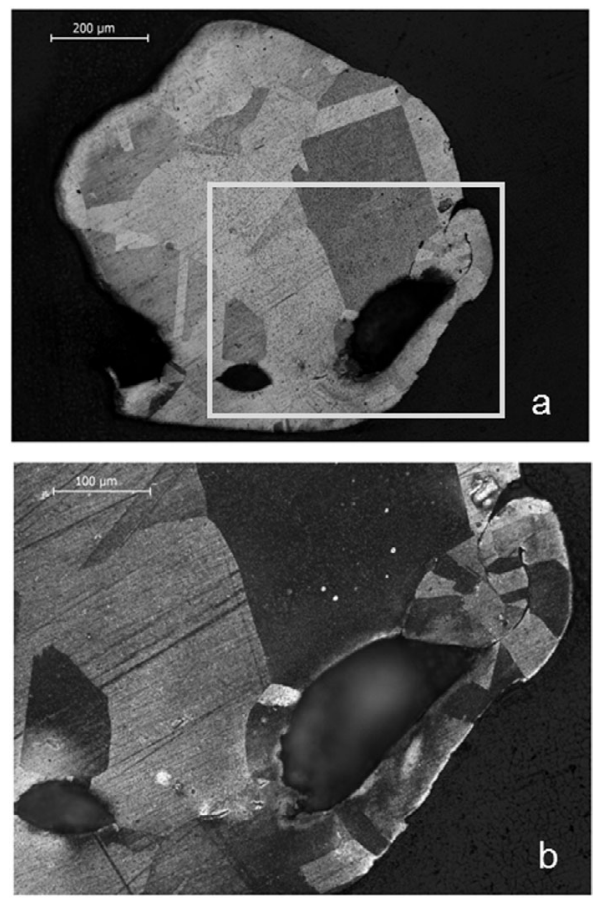

Fig. 7. Optical microscopy images of cross section of gold button 1719 from Outeiro da Cabeça: (a) entire cross section; (b) detail of rod and disk joining area (both BF cross-section, etched). and copper contents (Tab. 1, Fig. 10). The analysis of the individual button components using Micro-PIXE technique, as it was done with the gold buttons from Castro dos Ratinhos (Tab. 3), show that an evident similar compositional content exists among them. Minor differences are probably due to superficial corrosion processes that in gold alloys result in the removal of less noble elements from the surface of the artefacts. The presence of a superficial layer enriched in gold is confirmed by lower gold contents obtained by EDXRF analyses when compared with Micro-PIXE analyses (see Tabs. 1 and 3). The latter technique concerns a more superficial layer due to the low penetration depth of the protons when compared with the X-rays used by EDXRF (Araújo et al. 1993).

Three of these jewels were analyzed by the research group of Stuttgart (Outeiro da Cabeça $\mathrm{Au} 2755: 13 \% \mathrm{Ag}$ and $1.8 \% \mathrm{Cu}$; $\mathrm{Au} 2918: 10 \%$ $\mathrm{Ag}$ and $1.3 \% \mathrm{Cu}$; Fortios - $\mathrm{Au} 2746: 16 \% \mathrm{Ag}$ and $1.3 \% \mathrm{Cu}$ ) (Hartmann 1970). Au2918 corresponds to the gold button 1719 kept at Torres Vedras Museum. The alloy compositions obtained at Stuttgart are comparable to the values obtained by EDXRF in this work (Tab. 1).
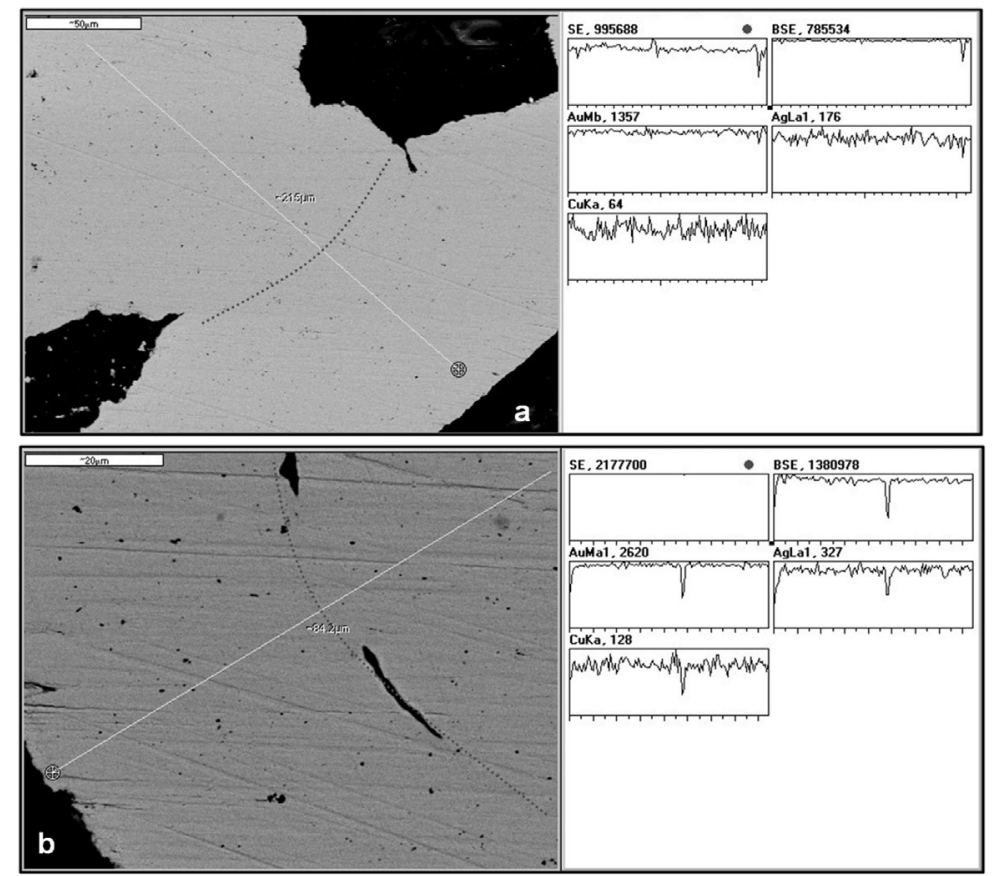

Fig. 8. EDS line scans of cross section of gold button 1719 from Outeiro da Cabeça (dotted line divides the rod and the disk button components: (a) top left: rod; bottom right: disk; and (b) top right: rod; bottom left: disk). 

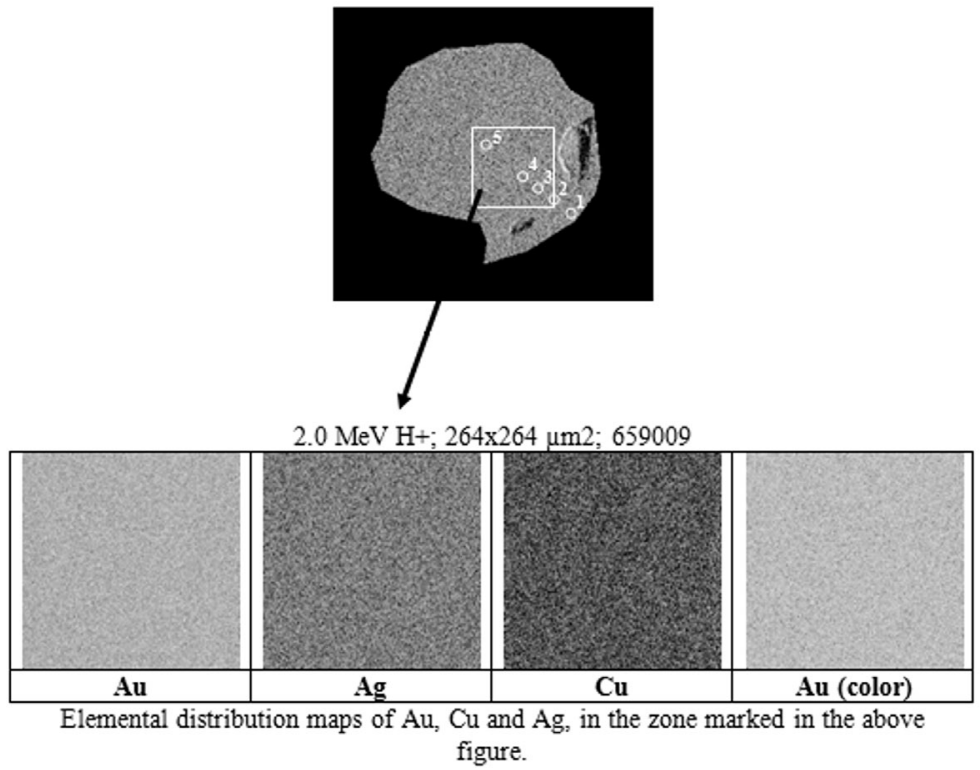

Quantitative results obtained from the points marked in the
\begin{tabular}{|l|lll|lll|lll} 
& \multicolumn{3}{c}{$\mathrm{Cu}$} & \multicolumn{1}{c}{$\mathrm{Ag}$} & \multicolumn{5}{c}{$\mathrm{Au}$} \\
\hline Point 1 & 1.25 & \pm & 0.01 & 8.5 & \pm & 0.2 & 90.3 & \pm & 0.9 \\
Point 2 & 1.74 & \pm & 0.02 & 8.8 & \pm & 0.2 & 89.4 & \pm & 0.9 \\
Point 3 & 1.30 & \pm & 0.01 & 9.6 & \pm & 0.3 & 89.0 & \pm & 0.9 \\
Point 4 & 1.17 & \pm & 0.01 & 8.9 & \pm & 0.2 & 89.9 & \pm & 0.9 \\
Point 5 & 1.20 & \pm & 0.01 & 9.7 & \pm & 0.3 & 89.1 & \pm & 0.9
\end{tabular}

Fig. 9. Micro-PIXE analyses of cross section of gold button 1719 from Outeiro da Cabeça.

A systematic study of gold artefacts dating from the Early Bronze Age to the Late Iron Age in Spain (Montero and Rovira, 1991), led the authors to point out to $25 \%$ of silver and $1 \%$ of copper as the conventional limits for natural gold

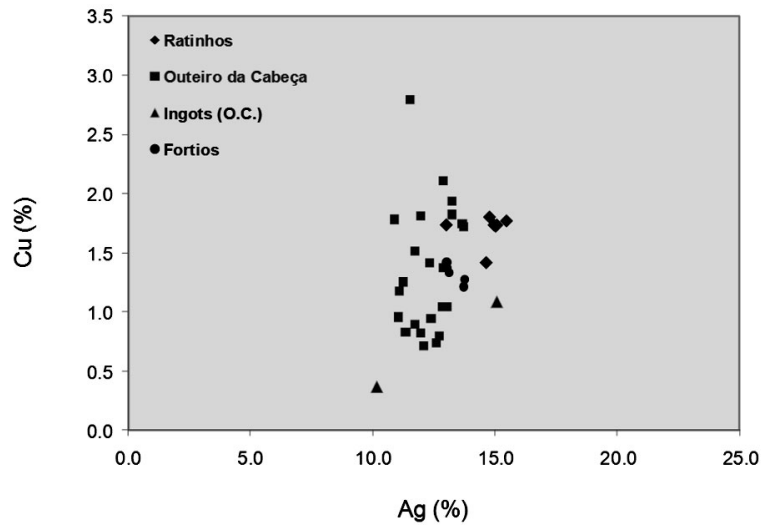

Fig. 10. Silver and copper contents of gold buttons from Castro dos Ratinhos, Outeiro da Cabeça and Fortios. Alloy composition of the two ingots from Outeiro da $\mathrm{Ca}-$ beça is also displayed. alloys. Furthermore, the study has shown that during the Late Bronze Age the silver content clearly increases, i.e. the majority of artefacts from earlier periods exhibit $5-10 \%$ of silver, while during the Late Bronze Age silver contents mostly range from $10-20 \%$. In this latter period the number of gold artefacts with copper contents higher than $1 \%$ also raises, probably as the result of the increased use of artificial alloys. During the transition from Late Bronze Age to Iron Age the heterogeneity of gold alloys also increase as a consequence of the rising influences from the Atlantic and Mediterranean areas (Perea 2005). The increasingly higher silver and, specially, copper contents in artefacts from the Late Bronze Age is commonly attributed to the above mentioned enhanced use of artificial gold alloys. However, in some particular cases this could derive from the exploitation of natural gold sources with higher silver and copper impurities. The alloy compositions of gold buttons from Castro dos Ratinhos, Outeiro da Cabeça and Fortios are consistent with this trend of increased silver and copper contents 
in gold alloys, although it is impossible to ascertain the natural or artificial nature of the alloy used.

Besides the buttons, other gold jewels, including two possible ingots, were found at Outeiro da Cabeça, as mentioned before. Alloy compositions of these jewels (Tab. 3) are very similar to those determined for the gold buttons suggesting a same origin, i.e. the gold buttons and the other jewels found at Outeiro da Cabeça were manufactured at the same gold workshop.

A previous study of pre-historic and proto-historic gold artefacts from the south of the Iberian Peninsula identified different types of welding processes (Perea 1990). Usually solder alloys with a melting point lower than the melting point of the components to be joined were used. The solder can be a gold-silver, gold-copper or gold-silvercopper alloy. Nevertheless, if the components to be joined are made from a similar gold alloy a different process can be used - a solid state diffusion welding. This process uses a temperature just below the alloy melting point and the bonding results from a solid state diffusion between components.

MICRO-PIXE, SEM-EDS and Om analyses prove that the analyzed gold buttons show no traces of any kind of solder material. If we carefully examine, even with naked eye, the joining regions of the buttons we can see that the disk and the tab thicknesses were strongly reduced in those regions turning into a very thin gold leaf (Figs. 11 and 12). Also at the outermost parts of some gold tabs it can be observed that during the joining disk/tab operation they had been molten (Fig. 11). These macroscopic observations together with the results obtained with the used analytical techniques - no traces of solder were identified - point out that, as all the gold alloy components of the buttons have the same elemental composition, the goldsmith after turned flat one of the components heated the region to be welded to temperatures closed to the melting point. For doing so, in the joining operation the goldsmith had to use a thin blowpipe to direct the flame to the very small area where the button components will be welded. This operation takes place always on the button reverse - the decorated rod is welded to disk from the back, since any kind of deformation is seen in the rod decoration, but some deformation due to melting can be observed sometimes on the button reverse or in the border of the disk at the region where the rod is placed (Figs. 11 and 12).
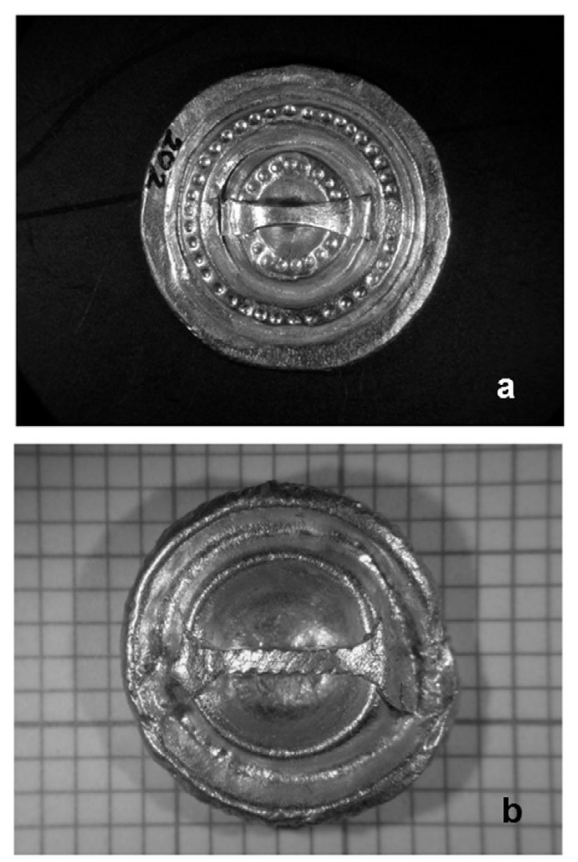

Fig. 11. Button reverses showing traces of molten flat tab ends, i.e. in the region where the tabs are joined to disks. $\mathrm{a}$ - button from Outeiro da Cabeça; $\mathrm{b}$ - button from Castro dos Ratinhos.
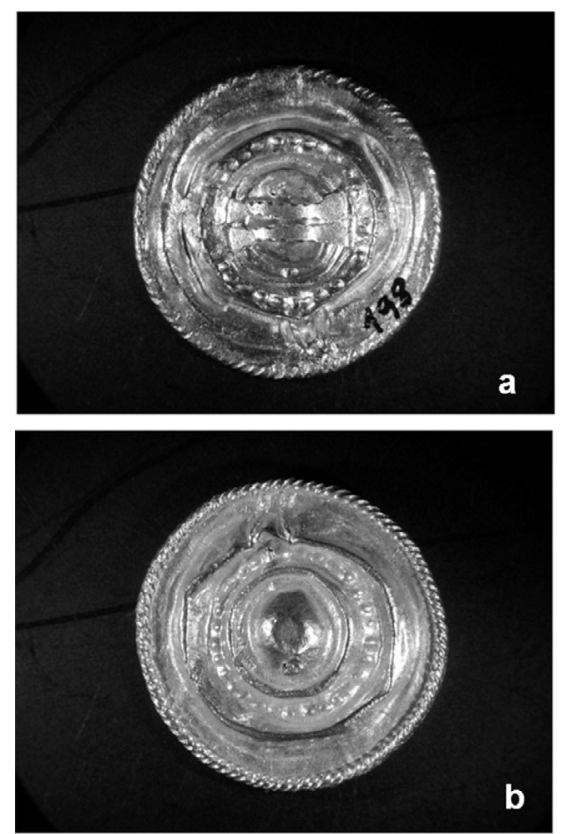

Fig. 12. Button Au198. a - reverse face showing a very thin disk thickness in button border, where some deformation can be seen in the rod decoration due to heat applied for welding the two components (rod/disk); b - obverse face showing the rod without any deterioration. 


\section{CONCLUSIONS}

Early Iron Age gold buttons from Castro dos Ratinhos, Outeiro da Cabeça and Fortios, archaeological sites located at South-Western Iberian Peninsula, present a rather similar alloy composition. Their silver and copper contents are characteristic of the gold metallurgy usually known from this period in the southwest of the Iberian Peninsula. Micro analyses show that the button components (disk, tab and peripheral decorated rod) are made from similar gold alloys that had been mechanically and thermally worked (forging and annealing). No solder alloy was identified in the welded areas. These results together with a macroscopic examination of the jewels indicate that a partial melting/solid state diffusion process was used for the welding of the button components. The analogous elemental compositions of the three sets of gold buttons and the very similar artefact typologies suggest that these small gold treasures could be interpreted as the result of the work of a single metallurgical workshop probably located somewhere in the South-Western Iberian Peninsula.

\section{REFERENCES}

Alves, L.C.; Araújo, M.F. and Soares, A.M.M. 2002: "Estudo de um torques proveniente do noroeste peninsular - aplicação de métodos instrumentais de análise química não destrutivos". O Arqueólogo Português S. IV, 20: 115-134.

Alves, L.C.; Breese, M.B.H.; Alves, E.; Paul, A.; Silva, M.R.; Silva, M.F. and Soares, J.C. 2000: "Micron-scale analysis of $\mathrm{SiC} / \mathrm{SiCf}$ composites using the new Lisbon nuclear microprobe". Nuclear Instruments and Methods in Physics Research B, 161: 334-338.

Araújo, M.F., Alves, L.C. and Cabral, J.M.P. 1993: "Comparison of EDXRF and PIXE in the analysis of ancient gold coins". Nuclear Instruments and Methods in Physics Research B 75: 450-453.

Berrocal-Rangel, L. and Silva, A.C. 2007: "O Castro dos Ratinhos (Moura, Portugal). Um complexo defensivo no Bronze Final do sudoeste peninsular".
In L. Berrocal-Rangel and P. Moret (eds.): Paisajes Fortificados de la Edad del Hierro: 169-190.

Bugoi, R.; Cojocaru, V.; Constantinescu, B.; Constantin, F.; Grambole, D. and Herrmann, F. 2003: "Micro-PIXE study of gold archaeological objects". Journal of Radioanalytical and Nuclear Chemistry 257: 375-383.

Demortier, G. 1991: "Étude de soudures sur quelques bijoux de l'Iran ancien par la technique PIXE". $L a$ Découverte du Métal: 425-437.

Demortier, G.; Morciaux, Y. and Dozot, D. 1999: "PIXE, XRF and GRT for the global investigation of ancient gold artefacts". Nuclear Instruments and Methods in Physics Research B 150: 640-644.

Ferreira, O.V. 1974: "Notícia da descoberta de jóias auríferas no distrito de Portalegre". Estudos Italianos em Portugal 37: 79-82.

Hartmann, A. 1970: Prähistorische goldfunde aus Europa. Gebrüder Mann Verlag, Berlin.

Heleno, M. 1935: "Joias pré-Romanas". Ethnos I: 229-257.

Montero, I. and Rovira, S. 1991: "El oro y sus aleaciones en la orfebrería prerromana". Archivo Español de Arqueologia 64: 7-21.

Perea, A. 1990: "Estudio microscópico y microanalítico de las soldaduras y otros procesos técnicos en la orfebrería prehistórica del Sur de la Península Ibérica". Trabajos de Prehistoria 47: 103-160.

Perea, A. 2005: "Relaciones tecnológicas y de poder en la producción y consumo de oro durante la transición Bronce Final-Hierro en la fachada atlántica peninsular”. Anejos de Aespa XXXV: 1077-1087.

Silva, A.C. and Berrocal-Rangel, L. 2005: "O Castro dos Ratinhos (Moura), povoado do Bronze Final do Guadiana: 1. ${ }^{a}$ campanha de escavações (2004)". Revista Portuguesa de Arqueología, 8: 129-176.

Soares, A.M.M.; Araújo, M.F. and Alves, L.C. 2004: "Análise química não-destrutiva de artefactos em ouro pré e proto-históricos: alguns exemplos". Revista Portuguesa de Arqueologia 7: 125-138.

Tertian, R. and Claisse, F. 1982: Principles of quantitative X-ray fluorescence analysis. Heyden \& Son, London.

Valério, P.; Alves, L.C.; Soares, A.M.M.; Berrocal-Rangel, L.; Silva, A.C. and Araújo, M.F. 2007: "Early Iron Age gold artefacts from Castro dos Ratinhos (Moura, Southern Portugal)". Proceedings of the $2^{\text {nd }}$ International Conference "Archaeometallurgy in Europe" (Aquileia, Italy. 17-21 June 2007). Milão: Associazione Italiana di Metallurgia. 9 (CD-Rom). 